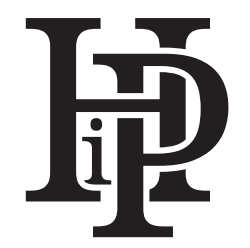

Historia i Polityka

$\mathrm{Nr}$ 35(42)/2021, ss. 47-60

www.hip.umk.pl (c) (1) $\odot$

ISSN 1899-5160, e-ISSN 2391-7652

DOI: http://dx.doi.org/10.12775/HiP.2021.003

Łukasz J UREŃCZYK

Uniwersytet Kazimierza Wielkiego, Wydział Nauk o Polityce i Administracji, Bydgoszcz, Polska

\title{
Polityczne i wojskowe aspekty stosunków między Chińską Republiką Ludową i niepodległym Sudanem Południowym
}

\section{Political and Military Aspects of Relations between the People's Republic of China and Independent South Sudan}

\section{- Abstrakt •}

Przedmiotem analizy są polityczne i wojskowe aspekty stosunków między Chińską Republiką Ludową i Sudanem Południowym. W pierwszej części artykułu omówiono aspekty polityczne, a w drugiej części aspekty wojskowe współpracy między państwami. Polityczno-wojskowe stosunki dwustronne zdominowane są kwestią konfliktów militarnych Sudanu Południowego. Chiny angażują się w działania na rzecz stabilizacji sytuacji bezpieczeństwa w Sudanie Południowym, jednak przede wszystkim koncentrują się na ochronie własnych interesów w tym państwie i regionie Afryki Wschodniej. Rozważania prowadzone są z perspektywy zarówno krajowej, jak i międzynarodowej.

Słowa kluczowe: Chińska Republika Ludowa; Sudan Południowy; stosunki polityczne; stosunki wojskowe

\section{- Abstract •}

The subject of the analysis are the politicalmilitary aspects of relations between the People's Republic of China and South Sudan. The first part of the article discusses political aspects and the second part discusses the military aspects of cooperation between states. Political-military bilateral relations are dominated by the issue of military conflicts of South Sudan. China is engaged in activities aimed at stabilizing the security in South Sudan, but above all it focuses on protecting its own interests in this country and the region of East Africa. The considerations are carried out from both a national and international perspective.

Keywords: People's Republic of China; South Sudan; political relations; military relations 


\section{Wprowadzenie}

Celem artykułu jest analiza i ocena politycznych i wojskowych aspektów stosunków Chińskiej Republiki Ludowej z Sudanem Południowym po uzyskaniu przez niego niepodległości. Problem badawczy zawiera się w pytaniach jaka jest intensywność i charakter polityczno-wojskowych stosunków między Chinami i Sudanem Południowym oraz jakie kwestie odgrywają w nich dominującą rolę. Główną tezą artykułu jest twierdzenie, że polityczno-wojskowe stosunki między państwami są bardzo ograniczone i charakteryzują się znaczną dysproporcją. Koncentrują się one na zaangażowaniu ChRL w rozwiązanie konfliktów zbrojnych Sudanu Południowego oraz zapewnieniu bezpieczeństwa personelowi i własności chińskich przedsiębiorstw naftowych. Tradycyjnie bliskie stosunki Chińskiej Republiki Ludowej z Sudanem po rozpadzie tego państwa pozostawiły pewne negatywne dziedzictwo na południu. Aby nawiązać i utrzymać poprawne i możliwie przyjazne stosunki z Dżubą, a jednocześnie nie pogorszyć ich z Chartum, Pekin musiał opracować wyważoną strategię i z wyczuciem realizował działania dyplomatyczne. Pierwsza dekada stosunków politycznych między Chinami i Sudanem Południowym co do zasady charakteryzowała się konstruktywnym podejściem stron. Niemniej jednak pojawiały się nieporozumienia, różnice zdań i rozbieżności interesów (Wani, 2018). Sudan Południowy stał się stroną poważnych konfliktów, zarówno o charakterze zewnętrznym, jak i wewnętrznym. Pekin nie pozostawił partnera w osamotnieniu, jednak sposób i skala jego zaangażowania w rozwiązanie tych waśni dla Dżuby nie były optymalne. $Z$ drugiej jednak strony Chiny wykazały dużą cierpliwość wobec władz Sudanu Południowego. Podczas badań skorzystano z metody analizy źródeł tekstowych.

\section{Aspekty polityczne}

W trakcie wojny w Sudanie ChRL przez wiele lat odgrywała rolę hamulcowego w kwestii zaangażowania się Organizacji Narodów Zjednoczonych w rozwiązanie kryzysu. Uległo to zmianie dopiero w połowie pierwszej dekady XXI w. W styczniu 2005 r. przedstawiciele Pekinu byli świadkami podpisania Całościowego Porozumienia Pokojowego (Comprehensive Peace Agreement), które kończyło 38-letnią wojnę domową między muzułmańskimi Arabami z północy a czarnymi chrześcijanami z południa państwa oraz powoływało Autonomiczny Rząd Sudanu Południowego (Autonomous Government of Southern Sudan - AGSS). Po tym przełomowym wydarzeniu zaczęły się odbywać pierwsze chińsko-południowosudańskie 
wizyty dyplomatyczne na najwyższych szczeblach politycznych. Prezydent AGSS i jednocześnie pierwszy wiceprezydent Sudanu - Salva Kiir Mayardit odwiedził Chiny w marcu 2005 r. i lipcu 2007 r. Z kolei w lutym 2007 r. prezydent Hu Jintao odbył pierwszą wizytę w Sudanie, podczas której spotkał się w Chartum z prezydentem Kiirem. Mimo odbywanych spotkań dyplomatycznych rząd Chin zachowywał względny dystans od liderów południowosudańskiego ruchu secesjonistycznego. Spowodowane to było utrzymywaniem bliskich stosunków politycznych z prezydentem Sudanu - Umarem Hasanem Ahmad al-Baszirem. Niemniej jednak we wrześniu 2008 r. Chiny otworzyły Konsulat Generalny w Dżubie (Embassy of the People's Republic of China in South Sudan, 2012).

Jeszcze pod koniec pierwszej dekady XXI w. relacje Komunistycznej Partii Chin (Communist Party of China - CPC) z kierowanym przez Kiira Ludowym Ruchem Wyzwolenia Sudanu (Sudan People's Liberation Movement - SPLM) były oziębłe. Gdy stało się wysoce prawdopodobnym, że Sudan Południowy utworzy własne państwo, przed CPC pojawiło się duże wyzwanie, aby je szybko znormalizować (Hodzi, 2017, s. 2). Ofensywie dyplomatycznej chińskiego rządu i partii komunistycznej towarzyszyły gesty pomocowe. Symptomatycznym przejawem wsparcia było ufundowanie szpitala w Bentiu, znajdującego się na terytorium dzisiejszego Sudanu Południowego (Soderlund, Briggs, 2014, s. 100).

W lutym 2011 r. Chiny, jako jedno z pierwszych państw na świecie, uznały pozytywny wynik przeprowadzonego na południu Sudanu referendum niepodległościowego. W jego konsekwencji 9 lipca 2011 r. Sudan Południowy ogłosił niepodległość. W uroczystości jej ogłoszenia prezydenta Hu Jintao reprezentował specjalny wysłannik ChRL - Jiang Weixin, minister mieszkalnictwa, rozwoju miast i obszarów wiejskich. Tego samego dnia, wraz ministrem spraw zagranicznych Sudanu Południowego - Dengiem Alor Kuolem, podpisał on w imieniu rządu Chin wspólny komunikat w sprawie nawiązania stosunków dyplomatycznych (Joint Communique on the Establishment of Diplomatic Relations). ChRL uznała w nim powstanie nowego państwa, z kolei Sudan Południowy ogłosił, że istnieją jedne Chiny reprezentowane przez rząd w Pekinie, których częścią jest Tajwan. Jeszcze tego samego dnia otworzona została Ambasada ChRL w Dżubie (Embassy of the People's Republic of China in South Sudan). Rząd Chin wysłał również depeszę uznania niepodległości Sudanu Południowego, w której zapisano, że był to efekt aspiracji i samodzielnej decyzji ludności Sudanu Południowego (Regler, 2016, s. 237). W ten sposób państwa nawiązały stosunki dyplomatyczne w dzień uzyskania niepodległości przez Sudan Południowy.

Proklamacja niepodległości przez Sudan Południowy zmusiła Pekin do prowadzenia bardzo ostrożnej i wyważonej gry dyplomatycznej, która miała zapewnić 
dobre stosunki jednocześnie z Dżubą, jak i z Chartum (Lanteigne, 2016, s. 16). Było to o tyle utrudnione, że szybko pogłębiał się konflikt miedzy państwami sudańskimi o kształt granicy i wysokość opłat za korzystanie z sudańskiej infrastruktury przesyłowej ropy naftowej. Mimo automatycznego uznania nowego państwa przez pewien czas utrzymywał się brak zaufania w stosunkach między Chinami i Sudanem Południowym (Ali, 2018, s. 117). W lutym 2012 r. prezes chińsko-malezyjskiego przedsiębiorstwa naftowego PetroDar - Liu Yingcai został wydalony z Sudanu Południowego. Powodem było jego uwikłanie się w spór między Dżubą a Chartumem o domniemaną kradzież ropy naftowej. Rząd Sudanu Południowego uznał działania Yingcaia za niekooperatywne. Było to o tyle symptomatyczne, że był to pierwszy obcokrajowiec wydalony z tego państwa (Hess, 2015, s. 4). Pod lupą Dżuby znalazły się również inne chińskie przedsiębiorstwa naftowe podejrzewane o sprzyjanie interesom północy.

Konflikt między państwami sudańskimi znacząco się zaostrzył 26 marca 2012 r., ponieważ rozpoczęły się intensywne walki graniczne o zlokalizowane tam pola naftowe. W dniach 23-26 kwietnia 2012 r. prezydent Kiir odbył państwową wizytę dyplomatyczną w Chinach. W jej trakcie spotkał się z prezydentem Jintao oraz innymi wysokimi przedstawicielami rządu ChRL i CPC, w tym z przyszłym premierem - Li Keqiangiem. Celem wizyty było omówienie płaszczyzn współpracy politycznej i gospodarczej między państwami (China Grants..., 2011). W wymiarze politycznym kluczowe było przedyskutowanie możliwości włączenia się Chin w działania na rzecz zakończenia konfliktu między Sudanem Południowym i Sudanem (Eberling, 2017, s. 209). Zarówno Dżuba, jak i Chartum oczekiwały wsparcia ze strony Pekinu i pomocy w negocjacjach. Chinom wprawdzie zależało na szybkim zakończeniu konfliktu, jednak chciały zachować bezstronność. Pekin stosował naciski dyplomatyczne na przywódców zwaśnionych stron, jednak wstrzymywał się od poważniejszej ingerencji w stosunki między państwami sudańskimi. Konflikt ten godził w interesy chińskich przedsiębiorstw naftowych, ponieważ Sudan Południowy wstrzymał wydobycie ropy naftowej. Ostatecznie we wrześniu 2012 r. udało się podpisać porozumienie pokojowe, a w marcu 2013 r. państwa wycofały siły zbrojne z obszaru granicznego. Miesiąc później Sudan Południowy wznowił wydobycie ropy i jej tranzyt przez terytorium Sudanu.

W marcu 2012 r. Sudan Południowy rozpoczął negocjacje akcesyjne do Wspólnoty Wschodnioafrykańskiej (East African Community - EAC). Chiny tradycyjnie popierające integrację gospodarczą państw afrykańskich pozytywnie odnosiły się do tej inicjatywy. Chińskie przedsiębiorstwa szybko zwiększały zaangażowanie gospodarcze w Afryce Wschodniej. W związku z tym Pekinowi zależało na rozwijaniu w regionie pokojowej współpracy. Wybuch wojny domowej w Sudanie Połu- 
dniowym spowodował jednak, że rozmowy te zostały zamrożone. Akcesja Sudanu Południowego do EAC stanęła pod znakiem zapytania ze względu na kwestie bezpieczeństwa (Khadigala, 2016, s. 181). Ostatecznie jednak w kwietniu 2016 r. podpisane zostały dokumenty akcesyjne, a po ich ratyfikacji, oficjalnie 5 września 2016 r., Sudan Południowy dołączył do wspólnoty. Jego członkostwo w EAC jest jednak obarczone pewnymi ograniczeniami w stosunków do tradycyjnych członków.

W 2013 r. wybuchła w Sudanie Południowym wojna domowa. Rozpoczęła się ona od rywalizacji politycznej między prezydentem Salva Kiirem z plemienia Dinków i wiceprezydentem Riek Macharem z plemienia Nuerów. Wiceprezydent Machar oskarżał prezydenta Kiira m.in. o skłonności dyktatorskie i dyskryminowanie Nuerów w życiu politycznym, gospodarczym i społecznym państwa. Za tę krytykę 23 lipca 2013 r. został on usunięty przez politycznego rywala ze stanowiska. W odpowiedzi 15 grudnia 2013 r. Machar przeprowadził nieudany zamach stanu, który przerodził się w wojnę domową między plemionami Dinków i Nuerów. W trakcie wojny domowej w Sudanie Południowym tylko do kwietnia 2018 r. zabitych zostało 190 tys. osób, a po uwzględnieniu takich czynników, jak przymusowe przesiedlenia, ograniczenie dostępu do opieki zdrowotnej i głód, pochłonęła ona szacunkowo 383 tys. ofiar (Specia, 2018). W trakcie wojny domowej dochodziło nawet do czystek etnicznych i ludobójstwa (Eberling, 2017, s. 209).

Pekin włączył się w mediację między ugrupowaniami wewnątrz Sudanu Południowego za pośrednictwem oddelegowanego specjalnego wysłannika, dobrze zaznajomionego z problematyką sudańską (Wissenbach, Wang, s. 257). Wyznaczył do tej roli Zhong Jianhua, pełniącego funkcję specjalnego przedstawiciela rządu ChRL ds. Afryki. Był on w stałym kontakcie z władzami z Sudanu Południowego. Ponadto dwa tygodnie po wybuchu konfliktu spotkał się w Addis Abebie z przedstawicielami południowosudańskiej opozycji zbrojnej. Co warte podkreślenia, spotkanie to odbyło się bez udziału przedstawicieli rządu w Dżubie. Oprócz nawiązania rozmów o możliwości zakończenia konfliktu, Chinom zależało jeszcze na dwóch kluczowych kwestiach. Pierwszą było upewnienie się, że ich pola naftowe nie są zagrożone. Drugą było zdobycie informacji o sile i planach rebeliantów na wypadek konieczności opowiedzenia się w przyszłości po którejś ze stron konfliktu (Hodzi, 2017, ss. 5-6). W styczniu 2014 r. w oficjalnym wystąpieniu minister spraw zagranicznych ChRL - Wang Yi wezwał liderów zwaśnionych stron do zakończenia prowadzenia działań zbrojnych (Copper, 2016, s. 50). Był to element zdecydowanej presji dyplomatycznej wywieranej na przywódców wrogich ugrupowań. Dnia 23 stycznia 2014 r. zawarte zostało pierwsze porozumienie o zawieszeniu broni, które było jednak nagminnie łamane. 
Początkowo ChRL formalnie nie była włączona w proces negocjacji, jednak odgrywała rolę wspomagającą, naciskając na strony, aby zawarły porozumienia. W latach 2014 i 2015 Chiny włączyły się do tego procesu w formie bardziej zinstytucjonalizowanej. Czyniły to za pośrednictwem Unii Afrykańskiej (African Union - AU), ONZ i Międzyrządowej Organizacji ds. Rozwoju (Intergovernmental Authority on Development - IGAD) skupiającej państwa Afryki Wschodniej. W ramach formuły IGAD+ partnerami rozmów południowosudańskich ugrupowań były państwa regionu, AU, ONZ, Chiny, Unia Europejska (European Union - EU), Stany Zjednoczone, Wielka Brytania i Norwegia. W styczniu 2015 r. ChRL zorganizowała w Chartum spotkanie, w którym wzięli udział m.in. ministrowie spraw zagranicznych Chin, Sudanu Południowego, Sudanu i Etiopii oraz przedstawiciele rebeliantów z Sudanu Południowego. Oficjalnie delegaci pozytywnie wypowiadali się o roli ChRL w procesie pokojowym. Żywili nadzieję, że dzięki ich zaangażowaniu możliwe będzie zawarcie porozumienia pokojowego. Działo się tak, mimo że uczestnicy zdawali sobie sprawę, że dla Pekinu priorytetowym celem organizacji spotkania było zabezpieczenie własnych interesów naftowych. W mniej oficjalnych wypowiedziach, niektórzy z delegatów spotkań odbywanych w ramach IGAD+, w tym przedstawiciele Norwegii i Ugandy, komentowali, że aktywność Chin w rozmowach pokojowych była niewielka, a momentami nawet problematyczna. Pojawiały się na przykład głosy, że reprezentanci ChRL niejednokrotnie w zbyt obcesowy sposób wywierali presję na Kiira i Machara (Hodzi, 2017, ss. 5-6). W sierpniu 2015 r. zawarta została kompromisowa umowa pokojowa (Compromise Peace Agreement), która pozwoliła na czasowe zawieszenie broni. W jej konsekwencji od kwietnia 2016 r. Machar ponownie pełnił funkcję wiceprezydenta państwa. Po trzech miesiącach doszło jednak do jego zdymisjonowania i ponownego wybuchu walk.

Jak wcześniej wspomniano w trakcie negocjacji Chiny przede wszystkim chciały zabezpieczyć własne interesy w Sudanie Południowym i regionie Afryki Wschodniej. W kontekście samych negocjacji pokojowych zależało im na tym, aby obie strony konfliktu były usatysfakcjonowane z zawartego porozumienia. Pekin Chciał uniknąć sytuacji, w której jedna strona odniosłaby sukces polityczny kosztem drugiej. Taki obrót spraw nie dawałaby bowiem podstaw dla utrzymania pokoju w dłuższym terminie. Podejście to wymuszało szukanie płaszczyzny kompromisu (Nyabiage, 2019). W praktyce dyplomaci ChRL odgrywali jednak rolę drugorzędną w poszukiwaniu punktów wspólnych. Pekin uzasadniał tą wstrzemięźliwość przywiązaniem do zasady nieingerencji w wewnętrzne sprawy państw. W praktyce niewielki zakres zaangażowania Chin w rozmowy pokojowe wynikał z ograniczonej możliwości oddziaływania na strony konfliktu, mimo dominującej pozycji 
ekonomicznej w Sudanie Południowym. We wrześniu 2018 r. doszło do zawarcia kolejnego porozumienia między ugrupowaniami Kiira i Machara. Zdecydowano o powołaniu rządu jedności narodowej, w którym Machar miał po raz kolejny odzyskać utraconą funkcję (Nyabiage, 2019). Ostatecznie 21 lutego 2020 r. Machar został mianowany wiceprezydentem w Odnowionym Rządzie Przejściowym Jedności Narodowej (Revitalised Transitional Government of National Unity).

W trakcie wojny domowej w Sudanie Południowym Pekin miał ograniczone możliwości zacieśniania stosunków politycznych z rządem w Dżubie. Pojawiały się jednak podmioty pozarządowe, które miały pozytywnie wpływać na klimat polityczny i stosunki między państwami a ich społeczeństwami. Przykładowo w lutym 2016 r. powołano Stowarzyszenie Przyjaźni Sudanu Południowego i Chin (South Sudan-China Friendship Association). Do zarządu stowarzyszenia weszli byli ministrowie spraw zagranicznych i spraw wewnętrznych obu państw (Bodetti, 2019). Jego misją jest promowanie przyjaznych relacji między społeczeństwami Chin i Sudanu Południowego. Z kolei 25 października 2019 r. w Dżubie odbyło się pierwsze forum think tanku Sudan Południowy-Chiny. Celem tego podmiotu jest zacieśnienie stosunków politycznych, ale także społecznych i gospodarczych między państwami. Wydarzenie koncentrowało się na trzech głównych obszarach, tj. polityce, dobrym zarządzaniu i gospodarce. Wzięli w nim udział naukowcy, badacze, eksperci, politycy i urzędnicy. Podczas forum drugi wiceprezydent państwa James Wani Igga powiedział, że ma ono doprowadzić do intensyfikacji współpracy między Sudanem Południowym i Chinami oraz pomóc rozwiązać problemy, które pojawiają się w relacjach dwustronnych (Xinhua, mingmei, 2019).

\section{Aspekty wojskowe}

Ewolucja podejścia Pekinu wobec misji pokojowych ONZ spowodowała, że do Sudanu udało się wprowadzić siły międzynarodowe w celu wsparcia tamtejszych procesów pokojowych. ChRL poparła rezolucję Rady Bezpieczeństwa (RB) ONZ nr 1590 z 24 marca 2005 r., na mocy której powołano Misję Narodów Zjednoczonych w Sudanie (United Nations Mission in Sudan - UNMIS), działającą na południu kraju w latach 2005-2011. Chiny zaangażowały się w UNMIS, utrzymując w niej w 2007 r. 435-osobowy personel wojskowy, w tym 275 osób z jednostek inżynieryjnych, 100 transportowców i 60 medyków (Attree, 2012, s. 22). Warto nadmienić, że w tym okresie ewoluowało także stanowisko Pekinu wobec konfliktu w Darfurze w Sudanie Zachodnim. Zmiana ta wynikała głównie z nacisków państw rozwijających się, w tym przede wszystkim państw afrykań- 
skich. Chiny, poczuwając się liderem państw rozwijających się i zwiększając swoje zaangażowanie gospodarcze w Afryce, nie mogły pozostać bierne wobec ich oczekiwań (Harnisch, 2016, s. 45). Naciski takie kierowane były jednak również ze strony państw Zachodu, w tym Stanów Zjednoczonych (Jia, 2016, s. 239).

Po uzyskaniu niepodległości Sudan Południowy stał się stroną dwóch poważnych konfliktów zbrojnych. Pierwszy toczony był przeciwko sąsiedniemu Sudanowi. W maju 2011 r., czyli jeszcze przed ogłoszeniem przez Sudan Południowy niepodległości, armia Sudanu dokonała aneksji spornej miejscowości Abyei w bogatym w ropę naftową regionie Kordofanu Południowego. Sudan Południowy wysyłał rebeliantów do regionu, w którym w czerwcu trwały zacięte walki. Strony 20 czerwca 2011 r. podpisały porozumienie o wycofaniu wojsk z regionu i rozmieszczeniu w nim sił międzynarodowych. Pekin poparł rezolucję RB ONZ nr 1990 z 27 czerwca 2011 r., na mocy której powołano Tymczasowe Siły Bezpieczeństwa Narodów Zjednoczonych dla Abyei (United Nations Interim Security Force for Abyei - UNISFA) (United Nations Security Council, 2011a). Większość żołnierzy do UNISFA skierowała Etiopia, a ChRL oddelegowała do niej jednego eksperta.

Ogłoszenie niepodległości przez Sudan Południowy 9 lipca 2011 r. nie doprowadziło do zakończenia konfliktu. Sudan Południowy nadal wysyłał bojowników do Kordofanu Południowego, dlatego tarcia graniczne nie ustawały. Ciężkie walki toczone były m.in. na przełomie marca i kwietnia 2012 r. o miejscowość Heglig. Południowosudańskiemu rządowi prezydenta Kiira zależało na zdestabilizowaniu sudańskiego rządu prezydenta Umara al-Baszira. Sudan zablokował dostęp południowosudańskiej ropy do swojej sieci przesyłowej i portów. To z kolei spowodowało zatrzymanie wydobycia surowca przez Sudan Południowy (Eberling, 2017, s. 208). Presja dyplomatyczna, m.in. ze strony Chin doprowadziła do podpisania porozumienia pokojowego we wrześniu $2012 \mathrm{r}$. W następnym roku istniało duże ryzyko wybuchu kolejnej wojny jednak spotkanie prezydentów Kiira i al-Baszira w Dżubie z 22 października 2013 r. pozwoliło na znaczne zmniejszenie napięć między państwami.

W dzień przed ogłoszeniem niepodległości przez Sudan Południowy Pekin poparł rezolucję RB ONZ nr 1996 z 8 lipca 2011 r. powołującą Misję Narodów Zjednoczonych w Republice Sudanu Południowego (United Nations Mission in South Sudan - UNMISS), która dzień później zastąpiła UNMIS (United Nations Security Council, 2011b). Chiny zaangażowały się również w tę misję i w 2012 r. utrzymywały w niej 360-osobowy kontyngent, złożony głównie z inżynierów, medyków i oficerów łącznikowych. W jego skład wchodził jednak także pluton o charakterze operacyjnym/bojowym, co było pierwszym w historii wysłaniem 
tego typu jednostek Chińskiej Armii Ludowo-Wyzwoleńczej (People’s Liberation Army - PLA) do misji pokojowej. Formalnie Pekin nie określa swoich sił kierowanych do misji ONZ w Afryce „jednostkami bojowymi” („zuozhan budui”). Określa je „kompleksowymi siłami bezpieczeństwa” (comprehensive security forces) (Lanteigne, 2016, s. 16) i podkreśla, że nie są one stroną konfliktów, a ich celem jest utrzymanie pokoju. Początkowo rolą plutonu stacjonującego w Sudanie Południowym była tylko ochrona chińskich pracowników (Cabestan, 2018, s. 2).

W dniach 19-20 lipca 2012 r. w Pekinie podczas 5. Konferencji Ministerialnej Forum Współpracy Chiny-Afryka (Forum on China-Africa Cooperation FOCAC) gospodarze przedstawili Plan Działania Pekinu (Beijing Action Plan) na lata 2013-2015, po raz pierwszy podkreślając znaczenie współpracy między Chinami i Afryką w zakresie utrzymania pokoju i bezpieczeństwa. Była to konsekwencja kryzysu w Libii, który spowodował nasilenie niestabilności w znacznej części Maghrebu i Sahelu. Osłabił on pozycję gospodarczą Chin w Libii oraz zwiększył ryzyko inwestycyjne w regionie. Aby zabezpieczyć swoje interesy w innych państwach Afryki, w tym w Sudanie Południowym, Chiny zdecydowały się na bardziej aktywne działanie (Hodzi, 2017, s. 4). Po wybuchu w grudniu 2013 r. wojny domowej w Sudanie Południowym Pekin zaczął się obawiać rozprzestrzenienia niestabilności do innych państw Afryki Wschodniej, w tym do Etiopii, Kenii i Ugandy, w których Chiny realizują duże inwestycje infrastrukturalne (Hodzi, 2017, s. 3). W związku z tym zdecydował się na wzmacnianie kontyngentu wojskowego w Sudanie Południowym, kierując do niego większe zgrupowanie sił operacyjnych. Podobne działanie dotyczyło misji pokojowej w Mali w Afryce Zachodniej.

W czerwcu 2014 r. rząd Chin zdecydował o wysłaniu do Sudanu Południowego batalionu piechoty w sile 700 żołnierzy. Była to pierwsza sytuacja w historii, kiedy Chiny wysłały do misji pokojowej tak dużą formację bojową (Regler, 2016, s. 237). Jego głównym celem była ochrona pól naftowych oraz chińskiego personelu i instalacji wydobywczych. Batalion rozmieszczony został głównie w stanach Unity i Nil Górny (Upper Nil). Część chińskich żołnierzy nadal stacjonowała jednak w Dżubie. Po tym wzmocnieniu liczebność chińskiego kontyngentu wzrosła do ponad tysiąca żołnierzy i w kolejnych latach utrzymywała się na tym poziomie (Nyabiage, 2019). Drastyczna redukcja nastąpiła dopiero w wyniku wystąpienia na świecie pandemii koronawirusa SARS-CoV-2 wywołującego chorobę COVID-19. Ograniczanie lub wycofywanie kontyngentów wojskowych z misji pokojowych było wtedy typowym działaniem większości państw.

Rząd w Pekinie z dużą determinacją naciskał na rząd w Dżubie, aby ten ochraniał chińskie pola naftowe w Unity i Nilu Górnym. Obszar ten był przedmio- 
tem rywalizacji między siłami rządowymi a rebeliantami, jednak rząd w Dżubie utrzymywał, że ma nad nim kontrolę (Bariyo, 2014). W rozmowie telefonicznej 14 kwietnia 2014 r. minister handlu Chin - Gao Hucheng poinstruował ministra spraw zagranicznych Sudanu Południowego - Barnabę Marial Benjamina, że Dżuba winna podjąć „środki siłowe” dla zachowania bezpieczeństwa chińskich inwestycji. 16 stycznia 2015 r. rząd Sudanu Południowego ogłosił, że chińskie instalacje naftowe przez cały czas znajdowały się pod kontrolą Ludowej Armii Wyzwolenia Sudanu (Sudan People’s Liberation Army - SPLA) (Hodzi, 2017, s. 6). Zapewnienia tego rodzaju nie były jednak wystarczające dla strony chińskiej, która zdecydowała się wykorzystać własnych żołnierzy.

W Dżubie 10 lipca 2016 r. zginęło dwóch żołnierzy chińskich, a kolejnych pięciu zostało rannych. Było to efektem próby wdarcia się rebeliantów na teren ochranianego przez żołnierzy ONZ obozu dla uchodźców. Pocisk artyleryjski trafił w pojazd opancerzony, w którym znajdowali się żołnierze (Pinghui, 2016). Po zamachu ewakuowany został personel ambasady ChRL w Dżubie i inni cywile. Warto nadmienić, że groźby ataków na obywateli Chin rezydujących w Sudanie Południowym pojawiały się regularnie (Ali, 2018, s. 118). Półtora roku później doszło w tym miejscu do podobnego zdarzenia, jednak obyło się bez ofiar (Huang, 2018). W Sudanie Południowym ofiarami ataków padali również cywilni obywatele ChRL. Najbardziej tragicznym w skutkach był atak z 19 października 2018 r. w Dżubie, w wyniku którego zginęło 14 chińskich pracowników lokalnego przedsiębiorstwa naftowego (Jatmika, 2018).

Poza zaangażowaniem PLA w misje pokojowe w Sudanie Południowym, stosunki wojskowe między państwami nie są rozwinięte. Inaczej niż w przypadku Sudanu, ChRL nie ma zawartych umów dwustronnych z Sudanem Południowym w zakresie wojskowości, obronności czy wymiany personelu wojskowego. W 2008 r., czyli jeszcze przed ogłoszeniem niepodległości przez Sudan Południowy, Chiny przekazały mu sprzęt do rozminowywania terenu i przeprowadziły kurs w tym zakresie dla personelu wojskowego. W ambasadzie Sudanu Południowego w Pekinie rezyduje attaché wojskowy, jednak nie przekłada się to znacząco na rozwój stosunków wojskowych między państwami.

Możliwość rozwinięcia współpracy w obszarze wojskowości, w tym sprzedaży broni do Sudanu Południowego, dyskutowana była m.in. podczas wizyty prezydenta Kiira w Pekinie w kwietniu 2012 r. Po wybuchu wojny domowej ChRL, w odróżnieniu od państw Zachodu, nie zdecydowała się na nałożenie sankcji gospodarczych na Sudan Południowy, w tym dotyczących eksportu broni do tego państwa. Teoretycznie dało to Chinom możliwość zwiększenia eksportu broni do Sudanu Południowego, w tym produkowanej przez China North Industries Gro- 
up (NORINCO). W czerwcu 2014 r. NORINCO miało zrealizować pierwszą dostawę broni do tego państwa o wartości $38 \mathrm{mln}$ USD. Realizacja kontraktu została jednak wstrzymana, ponieważ Zachód zaczął kwestionować pozytywną rolę ChRL w rozwiązywaniu konfliktu i zarzucił Pekinowi, że dostawa broni może go tylko pogłębić (Hodzi, 2017, ss. 3-4). Oficjalnie całościowa wartość dostarczonej przez Chiny broni do Sudanu Południowego wyniosła zaledwie $22 \mathrm{mln}$ USD. Niektórzy eksperci wskazują jednak, że mogło dochodzić do dostaw potajemnie lub za pośrednictwem innych państw (Eberling, 2017, ss. 213-214). Już w październiku 2011 r. Small Arms Survey udokumentował korzystanie przez grupy rebelianckie działające w Sudanie Południowym z nowo wyprodukowanych chińskich karabinów szturmowych typu 56-1. Pokazało to, że sprzedawana przez ChRL broń trafia w niepowołane ręce i wykorzystywana jest również przeciwko personelowi ONZ (Attree, 2012, s. 21). Po zawarciu porozumienia pokojowego między stronami w lipcu 2018 r. Pekin ogłosił, że włączy się w zaopatrywanie zjednoczonych sił bezpieczeństwa Sudanu Południowego w uzbrojenie i sprzęt wojskowy (Nyabiage, 2019).

\section{Zakończenie}

Z powodu dużej różnicy potencjałów stosunki między ChRL i Sudanem Południowym charakteryzują się znaczną asymetrią. O ile dla Sudanu Południowego Chiny są partnerem strategicznym, o tyle Sudan Południowy nie ma dużego znaczenia w polityce zagranicznej i bezpieczeństwa ChRL. Te dwie różne perspektywy czasem prowadzą do nieporozumień, a nawet konfliktów. Rządy obu państw zabiegają jednak o utrzymanie poprawnych, a nawet przyjaznych stosunków dwustronnych (Wani, 2018). Oczekiwania Dżuby wobec Pekinu muszą być realistyczne, a odrzucenie poszczególnych propozycji nie powinno pociągać za sobą celowego ochładzania relacji. $Z$ drugiej jednak strony dla utrzymania dobrych stosunków Chiny muszą wykazywać się wrażliwością na problemy wewnętrzne Sudanu Południowego. W interesie zarówno Dżuby, jak i Pekinu leży ustabilizowanie sytuacji w Sudanie Południowym, a co za tym idzie dalsze angażowanie się Państwa Środka w działania rozjemcze i pokojowe.

W celu realizacji własnych interesów politycznych i gospodarczych ChRL zdecydowała się zaangażować politycznie w rozwiązanie konfliktu zbrojnego między Sudanem Południowym i Sudanem oraz wojny domowej w Sudanie Południowym. Z jednej strony akcentowała ona zasadę nieingerencji w sprawy wewnętrzne, ale z drugiej gotowa była wywierać zdecydowaną presję na przywódców stron wal- 
czących. Pekin modyfikował strategię działania w zależności od rozwoju sytuacji. Wykorzystywał również różne formy współpracy, od dwustronnej po wielostronną. Chiny zdecydowały się również na wysłanie żołnierzy do misji pokojowej. W wymiarze propagandowym celem tego przedsięwzięcia było wsparcie wysiłków pokojowych zgodnie z oczekiwaniami mieszkańców Sudanu Południowego, jak i szerzej państw afrykańskich. W praktyce jednak ChRL koncentrowała się na ochronie własnych interesów politycznych i gospodarczych w Sudanie Południowym i w regionie Afryki Wschodniej.

W polityce zagranicznej i bezpieczeństwa ChRL wobec Sudanu Południowego widoczna była niespójność działania. Wynikała ona jednak z konieczności zręcznego balansowania między poważniejszym zaangażowaniem, a zachowaniem wizerunku państwa szanującego zasadę suwerenności państwowej oraz zachowującego bezstronność wobec stron konfliktu. Musiała to być wyważona gra dyplomatyczna, ponieważ w Afryce Chiny mają partnerów, dla których kwestia nieingerencji w sprawy wewnętrzne jest kluczowa. Często są to reżimy niedemokratyczne, jak na przykład w Angoli, obawiające się, że interwencja mocarstw może odsunąć je od władzy. Chiny co do zasady zachowywały więc pewną dozę wstrzemięźliwości, a na bardziej zdecydowane oddziaływanie decydowały się głównie w sytuacji konieczności ochrony własnych interesów. Mimo to zaangażowanie ChRL w rozwiązanie konfliktów Sudanu Południowego należy ocenić pozytywnie. Ponadto jeśli w Sudanie Południowym zapanuje pokój, Chiny potencjalnie mają duże możliwości intensyfikacji współpracy, m.in. w obszarze polityczno-wojskowym.

\section{Bibliografia:}

Ali, M.W. (2018). China and The Conflict in South Sudan: Security and Engagement. Journal of Economic, Administrative and Legal Sciences, 2(2), 111-128.

Attree, L. (2012). China and Conflict-Affected States. Between Principle and Pragmatism. London: Saferworld.

Bariyo, N. (2014.09.09). China Deploys Troops in South Sudan to Defend Oil Fields, Workers. The Wall Street Journal. Pobrane z: https://www.wsj.com/articles/china-deploys-troops-in-south-sudan-to-defend-oil-fields-workers-1410275041.

Bodetti, A. (2019.02.11). How China Came to Dominate South Sudan's Oil. The Diplomat. Pobrane z: https://thediplomat.com/2019/02/how-china-came-to-dominatesouth-sudans-oil/.

Cabestan, J.-P. (2018). China's Evolving Role as a UN Peacekeeper in Mali, Special Report of the United States Institute of Peace. Washington: USIP. Pobrane z: https://www. usip.org/sites/default/files/2018-09/sr432-chinas-evolving-role-as-a-un-peacekeeperin-mali.pdf. 
China grants South Sudan \$31.5m for Development Projects. (2011). Pobrane z: https:// www.sudantribune.com/spip.php?iframe\&page=imprimable\&id_article=40523.

Copper, J.F. (2016). China's Foreign Aid and Investment Diplomacy. Volume III. Strategy Beyond Asia and Challenges to the United States and the International Order. London-New York: Palgrave Macmillan.

Eberling, G.G. (2017). China's Bilateral Relations with Its Principal Oil Suppliers. London: Lexington Books.

Embassy of the People's Republic of China in South Sudan (2012). Sino-South Sudan Political Exchanges. Pobrane z: http://ss.chineseembassy.org/eng/sbgx/zjjw/.

Harnish, S. (2016). Role Theory and the Study of Chinese Foreign Policy. W: S. Harnisch, S. Bersick, J.-C. Gottwald (eds.). China's International Roles Challenging or supporting international order? (ss. 3-21). London-New York: Routledge.

Hess, S. (2015). Richard Aidoo, Charting the Roots of Anti-Chinese Populism in Africa. New York: Springer.

Hodzi, O. (2017). Strategy of 'Parallels': China in the South Sudanese Armed Conflict. Paris: Asia Centre. Pobrane z: https://centreasia.eu/en/strategy-of-parallels-china-in-thesouth-sudanese-armed-conflict- $2 /$.

Huang, K. (2018.01.06). Chinese Peacekeepers in Tense Stand-off with Armed Militants in South Sudan. Pobrane z: https://www.scmp.com/news/china/diplomacy-defence/ article/2127140/chinese-peacekeepers-tense-stand-armed-militants-south.

Jatmika, A. (2018.10.19). 14 Chinese Workers Killed in South Sudan. Pobrane z: https:// en.tempo.co/read/539251/14-chinese-workers-killed-in-south-sudan.

Jia, Q. (2016). Obama's Election: Its Implications for Sino-American Relations. W: Y. Hao (eds.). Sino-American Relations. Challenges Ahead (ss. 227-246). London-New York: Routledge.

Khadiagala, G.M. (2016). Region-Building in Eastern Africa. W: D.H. Levine, D. Nagar (eds.). Region-Building in Africa Political and Economic Challenges (ss. 175-190). Cape Town: Palgrave Macmillan.

Lanteigne, M. (2016). Chinese Foreign Policy. An Introduction. Third edition. LondonNew York: Routledge.

Nyabiage, J. (2019.10.05). Why China is Hoping for a Peace Dividend in South Sudan. South China Morning Post. Pobrane z: https://www.scmp.com/news/china/diplomacy/ article/3031640/why-china-hoping-peace-dividend-south-sudan.

Pinghui, Z. (2016.07.11). Two Chinese UN Peacekeepers Killed, Two Seriously Injured in Attack in South Sudan. Soutch China Morninng Post. Pobrane z: https://www.scmp. com/news/china/diplomacy-defence/article/1988348/two-chinese-un-peacekeepers-killed-two-seriously.

Regler, S. (2016). The Case of Darfur: Diplomacy under Influence of Sino-US Resource Rivalry. W: D. Zweig, Y. Hao (eds.). Sino-US Energy Triangles. Resource diplomacy under hegemony (ss. 226-242). London-New York: Routledge.

Soderlund, W.C., Briggs, E.D. (2014). The Independence of South Sudan: The Role of Mass Media in the Responsibility to Prevent (Studies in International Governance). Waterloo (Ontario): Wilfried Laurier University Press. 
Specia, M. (2018.09.26). 383,000: Estimated Death Toll in South Sudan's War. The New York Time. Pobrane z: https://www.nytimes.com/2018/09/26/world/africa/south-sudan-civil-war-deaths.html.

United Nations Security Council. (2005). Resolution 1590 (2005) Adopted by the Security Council at its 5151st Meeting, on 24 March 2005. Pobrane z: http://unscr.com/en/resolutions/doc/1590.

United Nations Security Council. (2011a). Resolution 1990 (2011) Adopted by the Security Council at its 6576th meeting, on 27 June 2011. Pobrane z: http://unscr.com/en/resolutions/doc/1990.

United Nations Security Council. (2011b). Resolution 1996 (2011) Adopted by the Security Council at its 6576th Meeting, on 8 July 2011. Pobrane z: http://unscr.com/en/resolutions/doc/1996.

Wani, D.C. (2018.10.02). China-South Sudan Relations: From Margin to the Spotlight. Modern Diplomacy. Pobrane z: https:/moderndiplomacy.eu/2018/10/02/china-southsudan-relations-from-margin-to-the-spotlight/.

Wissenbach, U., Wang, J. (2016). Development Policy: Alternatives, Challenges, and Opportunities. W: J. Wang, W. Song (eds.). China, the European Union, and the International Politics of Global Governance (ss. 251-270). New York: Palgrave Macmillan.

Xinhua, mingmei. (2019). Forum Seeks to Strengthen South Sudan-China Relations. Pobrane z: http://www.xinhuanet.com/english/2019-10/25/c_138503129.htm. 